\title{
Novel Comprehensive Molecular and Ecological Study Introducing Coastal Mud Shrimp (Solenocera Crassicornis) Recorded at the Gulf of Suez, Egypt
}

\author{
Eman M. Abbas ${ }^{1}$, Fawzia S. Ali ${ }^{1}$, Mohammed G. Desouky ${ }^{1}$, Mohamed Ashour ${ }^{1} \mathbb{D}$, Ahmed El-Shafei ${ }^{2,3, * \mathbb{D}}$, \\ Mahmoud M. Maaty ${ }^{1}$ and Zaki Z. Sharawy ${ }^{1, * \mathbb{D}}$ \\ 1 National Institute of Oceanography and Fisheries (NIOF), Cairo 11516, Egypt; \\ emanabbas03@yahoo.com (E.M.A.); dr_allam84@hotmail.com (F.S.A.); dr.mgaberniof@gmail.com (M.G.D.); \\ microalgae_egypt@yahoo.com (M.A.); mahmoudmaaty1@yahoo.com (M.M.M.) \\ 2 PSIPW Chair, Prince Sultan Institute for Environmental, Water and Desert Research, King Saud University, \\ Riyadh 11451, Saudi Arabia \\ 3 Department of Agricultural Engineering, College of Food and Agricultural Sciences, King Saud University, \\ Riyadh 11451, Saudi Arabia \\ * Correspondence: aelshafeilbn.c@ksu.edu.sa (A.E.-S.); zaki_sharawy@yahoo.com (Z.Z.S.); \\ Tel.: +966-11-4678504 (A.E.-S.); +20-10-0184-5218 (Z.Z.S.)
}

Citation: Abbas, E.M.; Ali, F.S.; Desouky, M.G.; Ashour, M.; El-Shafei, A.; Maaty, M.M.; Sharawy, Z.Z. Novel Comprehensive Molecular and Ecological Study Introducing Coastal Mud Shrimp (Solenocera Crassicornis) Recorded at the Gulf of Suez, Egypt. J. Mar. Sci. Eng. 2021, 9, 9. https:// dx.doi.org/10.3390/jmse9010009

Received: 19 October 2020

Accepted: 21 December 2020

Published: 23 December 2020

Publisher's Note: MDPI stays neutral with regard to jurisdictional claims in published maps and institutional affiliations.

Copyright: () 2020 by the authors. Licensee MDPI, Basel, Switzerland. This article is an open access article distributed under the terms and conditions of the Creative Commons Attribution (CC BY) license (https: / / creativecommons.org / licenses/by/4.0/).

\begin{abstract}
Solenocera crassicornis is a commercially important shrimp of the Solenoceridae family. The current study investigated the morphology, molecular identification, phylogenetic relationships, and population dynamics of S. crassicornis in Egypt. Samples were collected monthly (total, 1722; male $=40.19 \%$, wet weight, $0.89-10.77 \mathrm{~g}$; female $=59.81 \%$, wet weight, $1.55-19.24 \mathrm{~g}$ ) from Al-Attaka commercial catch in the Gulf of Suez in the Red Sea. Two barcode markers, $18 \mathrm{~S}$ rRNA and cytochrome c oxidase subunit I (COI), were used for molecular identification. COI partial sequences were used to construct the phylogenetic relationships among different species of genus Solenocera and to infer the origin of the studied Solenocera crassicornis. The applied molecular markers successfully identified the studied species to the species level. The genetic distances among S. crassicornis sequences from different countries revealed the Indo-West Pacific origin of S. crassicornis. The relationship between total length (TL) and total weight (TW) was TW $=0.035 \mathrm{TL}^{2.275}$ and $\mathrm{r}^{2}=0.805$ for males and TW $=0.007 \mathrm{TL}^{3.036}$ and $\mathrm{r}^{2}=0.883$ for females, indicating that females were heavier than males. Despite its social and economic relevance in the area, information on the hatching, larval rearing, and farming of S. crassicornis is scarce and requires future studies under Egyptian conditions.
\end{abstract}

Keywords: Penaeoidea; Solenoceridae; shrimp; Suez Gulf; Red Sea; DNA barcoding; 18S rRNA; COI

\section{Introduction}

Shrimp is presently the foremost important globally traded fishery product in terms of value. In numerous tropical developing countries, it is the most profitable fishery trade [1,2]. Shrimp fisheries are not only valuable food resources, but also major economic resources in Egypt and other developing countries. Worldwide, the commercial shrimp species is a one of the superfamily Penaeoidea, which is classified into five Penaeidean families: Penaeidae, Solenoceridae, Sicynoiidae, Aristeidae, and Sergestidae [3,4]. The Solenoceridae family has the economic importance for the commercial catch. All individuals are marine species, despite some juvenile Penaeidae species inhabiting brackish water and being occasionally found in almost fresh water. A significant species of the Solenoceridae family is Solenocera crassicornis, a member of the genus Solenocera Lucas, 1849, which comprises 38 species [5]. The common name of S. crassicornis (H. Milne Edwards, 1837), also identified as S. indicus (Nataraj, 1945), is the costal mud shrimp. It is an important commercial shrimp of Indian waters [6] and the main aquatic product for export in China [7]. This species is distributed along the West and East coasts of India; the coast of Malaysia, 
Mergui Archipelago, and Singapore, North Borneo, and Hong Kong; and the Indo-West Pacific (from the Malay Archipelago to India and Pakistan), Japan, and China. Its habitat depth is $40 \mathrm{~m}$, preferring the mud and sandy bottoms [5,8]. Several studies have been conducted on S. crassicornis dealing with some aspects of its fisheries and biology, such as age, growth, food, and feeding, breeding, and migration [8-10]; sustainable yield and population dynamic for S. crassicornis species in the East China Sea [11] and in the waters of Versova, Mombai [10]. Furthermore, Rajkumar et al. [12] investigated the morphological and molecular identification of S. crassicornis inhabiting the Coromandel Coast of Tamil $\mathrm{Nadu}$, India. The developing countries, including Egypt, are the primary producers of shrimp, due to extensive shrimp activities and overfishing. The demand for shrimp production and subsequent overexploitation can negatively impact shrimp stocks in water bodies in these countries. Therefore, regular assessment and management of fishery stock, particularly shrimp species of economic interest, is necessary. It is necessary to understand genetic structures to start breeding programs domestication and selection for aquaculture. Approximately 610 tons of shrimp are produced annually, and Penaeidae shrimp contribute to $8 \%$ of the total trawl landings [13]. The unparalleled geographic location of the Red Sea makes it highly sensitive to biodiversities, communities, and distributions [14]. Since the operation of the Suez Canal in 1872, the shrimp fauna in the Mediterranean has been enriched due to the changes and disturbances caused by the migration of some fish species and the partial change in the ecosystem. S. crassicornis was first recorded in the Mediterranean shelf of Egypt in 1981 by Abdel-Razek et al. [15], identified as S. indicus (Nataraj, 1945). However, there are no published data recording S. crassicornis in the Red Sea in Egypt. Additionally, there are no data available regarding the identification, occurrence, distribution, stock assessment, hatching, larval rearing, and farming of S. crassicornis in Egypt, despite it being an economically important species. The identification and characterization of aquatic organisms are considered a basic step for monitoring biodiversity and conserving such species [16-18]. In the case of crustaceans, morphology-based identification is an extremely basic science. Crustaceans undergo various larval stages with alterable and changeable shapes and background coloration due to chromatophores [19]. Therefore, this identification tool can be ineffective and misleading [20,21]. In such cases, the application of molecular-based identification tools, including DNA barcoding, can resolve these problems. DNA barcoding applies universal primers to amplify a targeted genomic region. The efficiency of this method depends on the diverse nature of the targeted region among species [22,23]. In crustaceans, targeting the region of the cytochrome oxidase subunit I (COI) mitochondrial gene using the primer pairs described by Folmer et al. [24] was the most efficient. DNA barcoding is a perfect tool for identification and studying species diversity within an ecosystem. Several studies have used the COI region to identify various crustaceans [12,25-27]. Some of the shrimp species of economic interest in Egypt have been precisely characterized using morphological and genetic analyses [28-31]. Here, we conducted a comprehensive study of S. crassicornis collected from the Gulf of Suez in Egypt, including molecular identification, growth parameter assessments, and estimations of population dynamic parameters. We integrated two barcode regions, namely, $18 \mathrm{~S}$ rRNA nuclear barcode and COI mitochondrial barcode, with morphological identification data to precisely characterize the studied species. Additionally, monthly variations in length frequency were used to determine $S$. crassicornis growth parameters and to estimate other population dynamic parameters.

\section{Materials and Methods}

\subsection{Sample Collection and Morphology}

Random S. crassicornis samples were collected monthly for 12 months starting from June 2019 by trawl nets from Al-Attaka commercial catch in the Gulf of Suez, the Red Sea. The collected shrimp samples were identified as S. crassicornis (H. Milne Edwards, 1837) based on morphological characteristics, as described in the literature $[8,9,15]$. The length 
frequency for 1722 S. crassicornis individuals, comprising 692 males $(2.3-11.0 \mathrm{~cm})$ and 1030 females $(3.9-13.3 \mathrm{~cm})$, was estimated.

\subsection{Growth Parameters and Population Dynamics}

\subsubsection{Population structure}

To prevent prejudice due to various measuring tools for researchers and for a more accurate methodology, we estimated singular lengths to the closest $0.1 \mathrm{~cm}$ by using a MATLAB routine (MathWorks Inc., Natick, MA, USA) to singular shrimp snapshots taken with a MEGA 0.I.S USB camera (Leica, Wetzlar, Germany) outfitted with a DC VARIOELMARIT 1:2.8-49/6.3-25.2 A SPH lens (Leica). The snapshots created a record that could be easily stored and used for additional estimations and confirmatory checks if necessary. Manual fixation of singular shrimp with a complete rostrum on millimeter paper was done (to stay away from the natural warp of the shrimp body). The estimations were characterized as: (a) Total length (TL): The space from the tip of the rostrum to the end of the telson, $\mathrm{cm}$; (b) carapace length (CL): The space from the posterior margin of the orbit to the posterior edge of the carapace, $\mathrm{mm}$; and (c) total weight (TW): Weighed in grams by using an electronic digital balance ( $\pm 0.01 \mathrm{~g}$; Sartorius, Göttingen, Germany).

\subsubsection{Growth Parameters, Mortality, and Exploitation Rates}

We applied the ELEFAN1 program to length frequency inputs to evaluate asymptotic length $\left(\mathrm{L}_{\infty}\right)$ and to estimate the growth coefficient $(\mathrm{K})$ for each sex separated utilizing von Bertalanffy growth function (VBGF) development work [32] as follows:

$$
\mathrm{Lt}=\mathrm{L}_{\infty}\left[1-\mathrm{e}^{-\mathrm{K}(\mathrm{t}-\mathrm{t} 0)}\right]
$$

where: $L t$ is TL at age $t, L_{\infty}$ is the asymptotic $T L, K$ is the curvature value, and $t_{0}$ is the theoretical age when TL is zero.

To compare the growth performance of both males and females [33] as follows:

$$
\varphi=\log _{10} \mathrm{k}+2 \log _{10} \mathrm{~L}_{\infty}
$$

where: $\mathrm{K}$ and $\mathrm{L}_{\infty}$ are Bertalanffy equation constant.

The instantaneous rate of natural mortality (M) was also estimated [33] as follows:

$$
\log 10(\mathrm{M})=-0.0066-0.279 \log 10(\mathrm{~L} \infty)+0.6543 \log 10(\mathrm{~K})+0.4634 \log 10(\mathrm{~T})
$$

where: $\mathrm{T}$ is the temperature of water.

Total mortality instantaneous rate (Z) was evaluated by applying the FiSAT II program, using a length-converted fishing curve [34] according to the equation $\ln (\mathrm{N} / \Delta \mathrm{t})=\mathrm{a}+\mathrm{bt}$, where $\mathrm{N}$ is the number of crabs in a particular size class, $\Delta t$ is the time required to attain that class (years), $t$ is the relative age (years), $a$ is the intercept, and $b$ is the regression coefficient $(b=Z)$. Hence, fishing mortality $(F)$ for both sexes were estimated as $F=Z-M$. Then, the exploitation rates (E) were estimated as the following: $\mathrm{E}=\mathrm{F} / \mathrm{Z}$ [35]. As indicated by Pauly [36], the ascending left arm of the CL-converted catch curve was utilized to examine the probability of capture of every length class. The modified Beverton and Holt [37] relative yield per recruit $(\mathrm{Y} / \mathrm{R})$ model by Pauly and Soriano [38] was utilized and then incorporated into FiSAT II programming to gauge the degrees of exploitation that would give ideal yields. Investigations of $\mathrm{E}_{\max }$ (the exploitation rate giving highest relative yield per recruit), $\mathrm{E}_{0.1}$ (exploitation rate at which the marginal raise in $\mathrm{Y} / \mathrm{R}$ is $10 \%$ of its value at $\mathrm{E}=0$ ), and $\mathrm{E}_{0.5}$ (the identical exploitation to half of the unexploited relative biomass per recruit, $\mathrm{B} / \mathrm{R}$ ) were evaluated.

To assess the allometry, the TW-TL relationship, the equation of Le-Cren's [39] was used as follows:

$$
\mathrm{TW}=\mathrm{a} \mathrm{TL}^{\mathrm{b}}
$$


where: TL (cm): Is the carapace length, TW $(\mathrm{g})$ : Is the total body wet weight, while a is intercept parameter and $\mathrm{b}$ is allometric parameter.

\subsection{Molecular Analysis}

\subsubsection{DNA Extraction and Polymerase Chain Reaction Amplification}

Genomic DNA was extracted from the axial muscle of the collected samples, according to Sambrook et al. [40]. Briefly, 100-200 mg of muscle tissue sample was ground in TES buffer (10 mM Tris- $\mathrm{HCl}, 25 \mathrm{mM}$ EDTA, $140 \mathrm{mM} \mathrm{NaCl}$, and $\mathrm{pH} 7.8$ ) containing $0.5 \mathrm{mg} \mathrm{mL}^{-1}$ proteinase $\mathrm{K}$ and $1 \% \mathrm{SDS}$. The homogenates were incubated for $2 \mathrm{~h}$ at $56^{\circ} \mathrm{C}$. Total genomic DNA was extracted using a conventional phenol-chloroform procedure and precipitated with absolute ethanol. The DNA pellets were eluted in TE buffer $(100 \mathrm{mM}$ Tris- $\mathrm{HCl}$ and $10 \mathrm{mM}$ EDTA, $\mathrm{pH}$ 8). The concentrations of DNA of all samples were measured using a Nanodrop spectrophotometer (Biodrop, Cambridge, England). Following DNA isolation, two barcode regions were amplified for species identification, namely, a 683-bp fragment from the coding region of the mitochondrial gene (COI) and a 469-bp partial fragment of the $18 \mathrm{~S}$ rRNA nuclear gene. Polymerase Chain Reaction (PCR) was performed on a GeneAmp PCR System 9700 Thermal Cycler (Applied Biosystems, Foster City, CA, USA) utilizing the primer pairs LCO1490 (5'-GGTCAACAAATCATAAAGATATTGG-3') and HCO2198 (5'-TAAACTTCAGGGTGACCAAAAAATCA-3') [24], and Ebi18S-F (5'CGCCTACAATGGCTATAACGGGTAAC-3'), and Ebi18S-R (5'-GGTTAGAACTAGGGCG GTATCTGATC-3') [29] for COI and 18S rRNA amplification, respectively. The PCR reactions were conducted in $25 \mu \mathrm{L}$ as a total volume containing $12.5 \mu \mathrm{L}$ of 1x MyTaqTM HS Red Mix (Bioline, London, UK), $30 \mathrm{ng}$ of template DNA, and $0.4 \mu \mathrm{M}$ of each primer. The PCR program for amplification of the COI region was: Initial denaturation for $5 \mathrm{~min}$ at $94^{\circ} \mathrm{C}$, followed by 40 cycles of denaturation for $1 \mathrm{~min}$ at $94{ }^{\circ} \mathrm{C}$, annealing for $1 \mathrm{~min}$ at $45^{\circ} \mathrm{C}$, and extension for $1.30 \mathrm{~min}$ at $72{ }^{\circ} \mathrm{C}$, and a final extension for $7 \mathrm{~min}$ at $72{ }^{\circ} \mathrm{C}$. The cycling profile for $18 \mathrm{~S}$ rRNA amplification was: Denaturation for $5 \mathrm{~min}$ at $95^{\circ} \mathrm{C}$, followed by 35 cycles of denaturation for $30 \mathrm{~s}$ at $95^{\circ} \mathrm{C}$, annealing for $30 \mathrm{~s}$ at $48{ }^{\circ} \mathrm{C}$, and extension $\mathrm{C}$ for $2 \mathrm{~min}$ at $72^{\circ}$, and a final extension for $7 \mathrm{~min}$ at $74^{\circ} \mathrm{C}$. The amplicons were electrophoresed at $120 \mathrm{~V}$ on a $2.5 \%$ agarose gel and stained with ethidium bromide $\left(25 \mu \mathrm{g} \mathrm{mL}{ }^{-1}\right)$ for visualization. PCR products having single bands with the expected amplicon size were purified using Isolate II PCR and Gel Kit (Bioline). The purified PCR products were sequenced using a BigDye Terminator v3.1 Cycle Sequencing Kit [41] on an ABI 3730 Sequencer (both Applied Biosystems). The sequencing reaction was applied as follows: $96^{\circ} \mathrm{C}$ for $2 \mathrm{~min}$, followed by 25 cycles at $96^{\circ} \mathrm{C}$ for $10 \mathrm{~s}$, at $50{ }^{\circ} \mathrm{C}$ for $5 \mathrm{~s}$, and at $60^{\circ} \mathrm{C}$ for $4 \mathrm{~min}$.

\subsubsection{Sequencing and Phylogenetic Analysis}

The raw data of sequences for COI and 18S rRNA were treated using the free software Chromas Lite v2.1 (Technelysium Pty Ltd., available from http:/ /technelysium.com.au/) and compared with the available sequences in the databases of GenBank (https: / /blast. ncbi.nlm.nih.gov/Blast.cgi) using BLAST searches. The COI sequences were also compared using the Barcode of Life Data System (BOLD) species identification portal (http:/ / www. barcodinglife.org). A Barcode Index Number (BIN) was assigned [42] for the COI sequences of the study specimens, to confirm their concordance with sequence clusters available in the BOLD database. The partial coding sequences of COI (683 bp) and 18S rRNA (469 bp) of the investigated samples were deposited in the GenBank, EMBL, and DDBJ global databases under the accession numbers LC477203-LC477205 and LC477340. Due to the abundance of the available COI sequences on the GenBank Database compared to $18 \mathrm{~S}$ rRNA sequences, COI barcode region was used as a reference region for further molecular analysis. COI sequences for Solenocera species were retrieved from the GenBank database and aligned with the obtained sequences of the Egyptian S. crassicornis by CLUSTALW software in MEGAX [43]. To locate S. crassicornis in relation to its relatives from the same genus, the genetic distances among species of Solenocera were estimated based on Kimura two-parameter distance model (K2P) using Group Mean Distance software impeded in 
MEGAX software package. MEGAX was used to apply the best fitting models to the COI datasets of nucleotide sequences and disparity estimates using the general time-reversible model [44]. Phylogenetic trees were constructed in MEGAX using the method of maximum likelihood (ML), with 1000 bootstrap replicates.

\section{Results}

\subsection{Morphology, Population Dynamics, and Growth Parameters}

\subsubsection{Morphology}

The body and legs of S. crassicornis are reddish (Figure 1). The antennules were banded with white and dark red. Except for some white areas, the uropods were dark red. The rostrum is short and extends to approximately 2-3 of the eyes, with an upper border with 7 to 8 teeth and a robustly convex lower border. The postrostral crest was obviously raised, slightly interrupted by a little notch over the cervical groove, and the height of the posterior section gradually decreases posteriorly. The orbital, antennal, hepatic spines, and postorbital were unmistakable on the carapace, however, without pterygostomian spines. The hepatic spine closes at the edge of a little round pit just behind the pterygostomian angle. The orbital edge sharp, there was a little postorbital pit over the postorbital spine, and the branchiocardiac carina and sulcus were well determined. The antennular flagella were sensibly long and tube-like. The telson has a couple of horizontal spines.

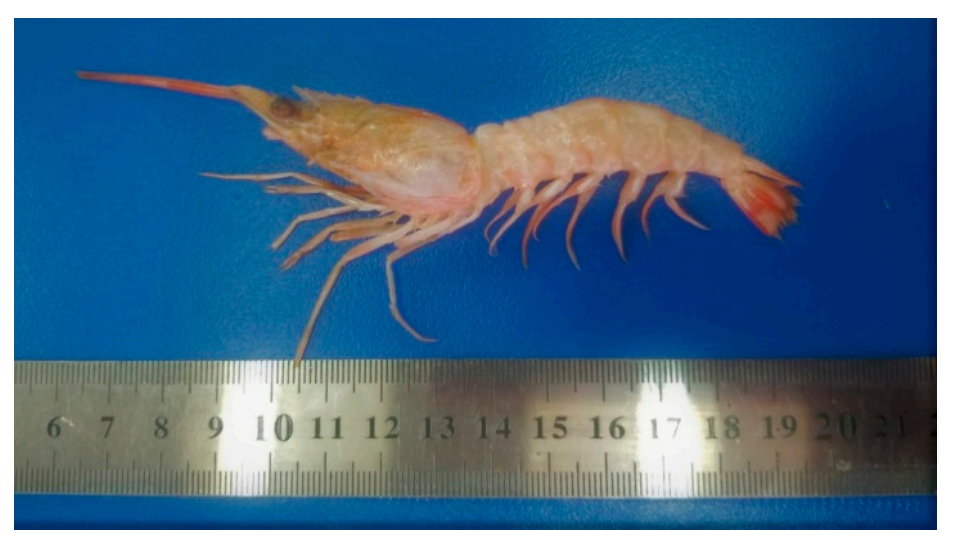

Figure 1. Solenocera crassicornis (H. Milne Edwards, 1837) caught from Al-Attaka, the Gulf of Suez, Red Sea of Egypt.

All shrimp samples were pooled by sex to determine relationships between TL-TW and TL-CL ( $n=1722$; male, $40.19 \%$; female, 59.81\%) were analyzed as shown in Figures 2 and 3. The TW were ranged from 0.89 to $10.77 \mathrm{~g}$ and from 1.55 to $19.24 \mathrm{~g}$ for males and females, respectively. While the TL ranged from 2.3 to $11.0 \mathrm{~cm}$ and from 3.9 to $13.3 \mathrm{~cm}$ for males and females, respectively. Meanwhile, CL were ranged from 0.9 to 3.2 and from 1.3 to $4.5 \mathrm{~cm}$ for males and females, respectively.
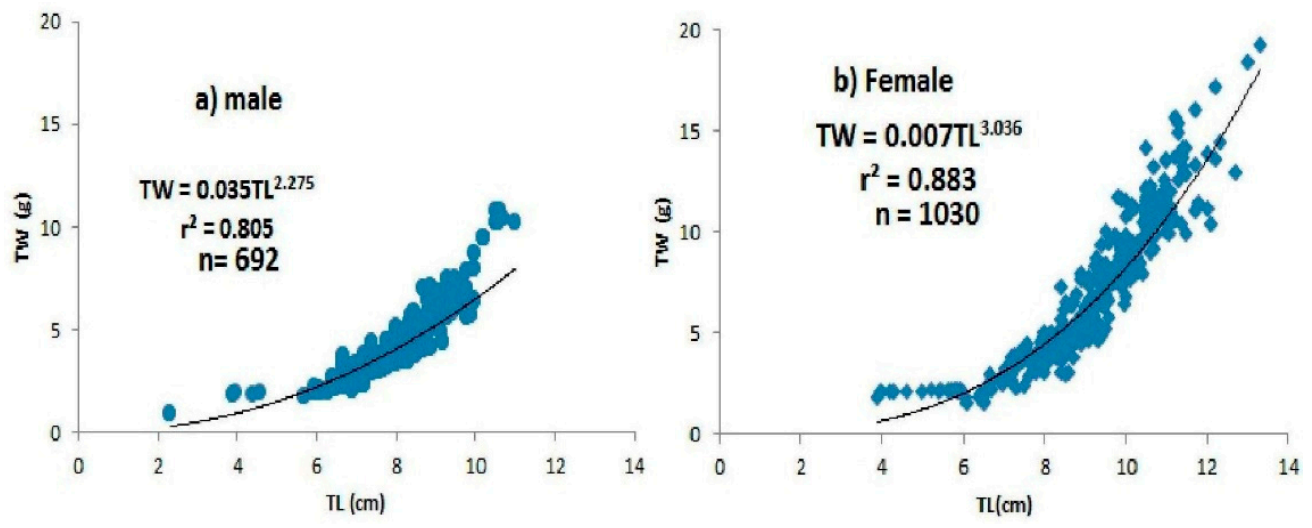

Figure 2. Length-weight relationship for males (a) and females (b) of S. crassicornis from the Gulf of Suez, Egypt. 

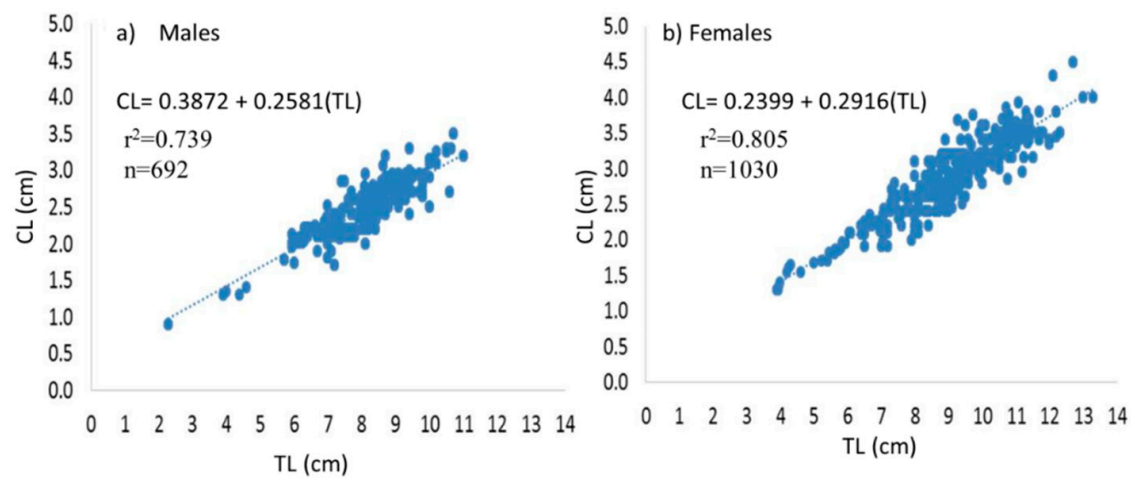

Figure 3. The relationship between total length and carapace length for males (a) and females (b) of S. crassicornis from the Gulf of Suez, Egypt.

\subsubsection{TL-TW Relationship}

The length-weight relationship between (TL) and total weight (TW) was TW $=0.035 \mathrm{TL}^{2.275}$ and $\mathrm{r}^{2}=0.805$ for males and TW $=0.007 \mathrm{TL}^{3.036}$ and $\mathrm{r}^{2}=0.883$ for females. Overall, TW regression analyses showed positive allometric growth $(b>3)$ in females in contrast with males (negative allometric growth), indicating that females were heavier than males with a growing length TL (Figure 2).

\subsubsection{TL-CL Relationship}

A linear equation was estimated for males as $C L=0.3872+0.2581(\mathrm{TL}), \mathrm{r}^{2}=0.7394$, and $C L=0.2399+0.2916(\mathrm{TL}), \mathrm{r}^{2}=0.805$ for females. The size of the female carapace was larger than that of the male (Figure 3).

\subsubsection{Growth Parameters}

The growth parameters evaluated using ELEFAN1 for males and females were $\mathrm{L}_{\infty}=115.5 \mathrm{~mm}$ and $136.5 \mathrm{~mm}$, respectively, with $\mathrm{K}=0.76 \mathrm{yr}^{-1}$ and $\mathrm{t} 0=-0.0366$ for males and $\mathrm{K}=1.1 \mathrm{yr}^{-1}$ and $\mathrm{t} 0=-0.08184$ for females.

The VBGF was $\mathrm{Lt}=115.5\left[1-\mathrm{e}^{-0.76(\mathrm{t}+0.0366)}\right]$ for males and $\mathrm{Lt}=136.5\left[1-\mathrm{e}^{-1.1(\mathrm{t}+0.8184)}\right]$ for females.

The obtained results of growth performance index $(\varphi)$ were 4.01 and 4.31 for males and females, respectively.

\subsubsection{Mortality Rate}

Total mortality $(\mathrm{Z})$ for males $=3.99 \mathrm{yr}^{-1}$ and females $=3.05 \mathrm{yr}^{-1}$, while the natural mortality (M) was $1.91 \mathrm{yr}^{-1}$ and $1.35 \mathrm{yr}^{-1}$ for males and females, respectively. Fishing mortality (F) for males and females were $2.08 \mathrm{yr}^{-1}$ and $1.70 \mathrm{yr}^{-1}$, respectively. Meanwhile, exploitation rates (E) were 0.52 and 0.56 for males and females, respectively (Figure 4).
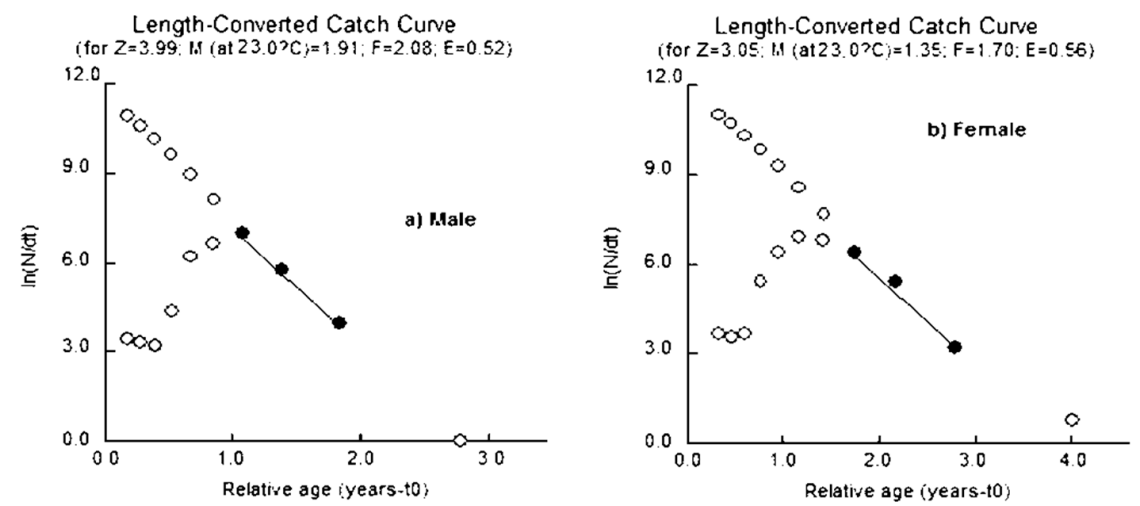

Figure 4. Cumulated catch curve based on length composition data for males (a) and females (b) of S. crassicornis from the Gulf of Suez, Egypt. 


\subsubsection{Length at First Capture}

The length at first capture (LC), at which $50 \%$ of the shrimp are vulnerable to capture (L50\%), was estimated as $72.3 \mathrm{~mm}$ and $94.6 \mathrm{~mm}$ for males and females, respectively (Figure 5).
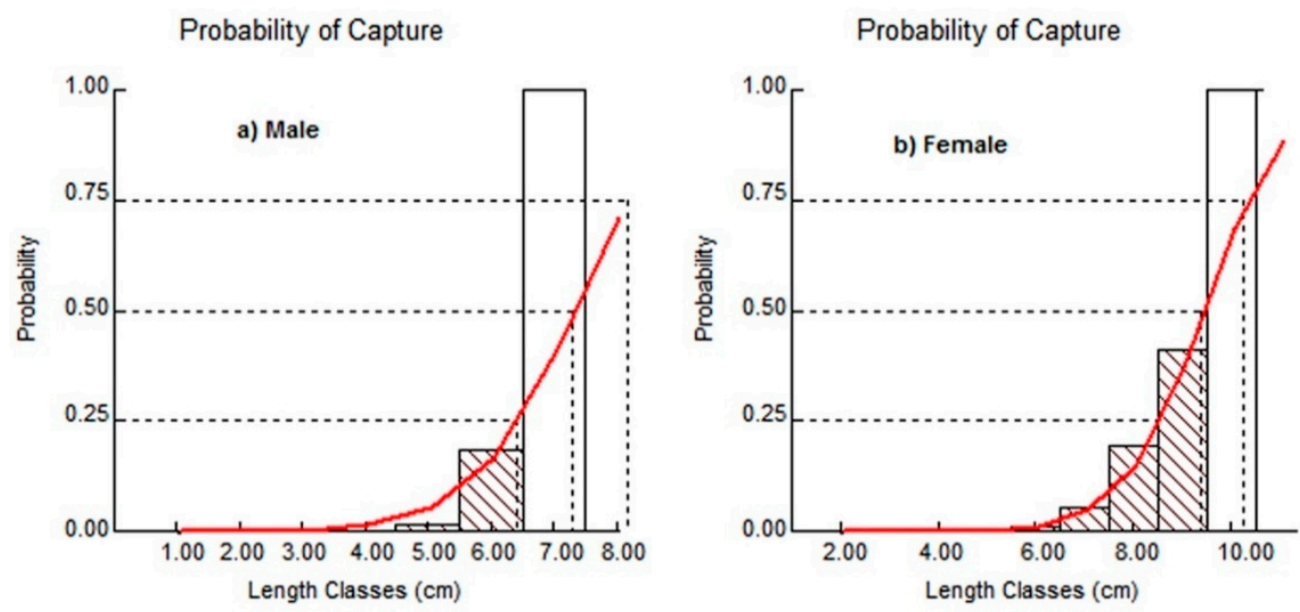

Figure 5. Probability of capture (L50\% or LC) for males (a) and females (b) of S. crassicornis from the Gulf of Suez, Egypt.

\subsubsection{Relative Yield per Recruit}

The relationships between $Y / R$ and $B / R$ of both males and females showed that $E_{\max }$, $E_{0.1}$, and $E_{0.5}$ were the same for males and females $(0.421,0.355$, and 0.278 , respectively) (Figure 6).
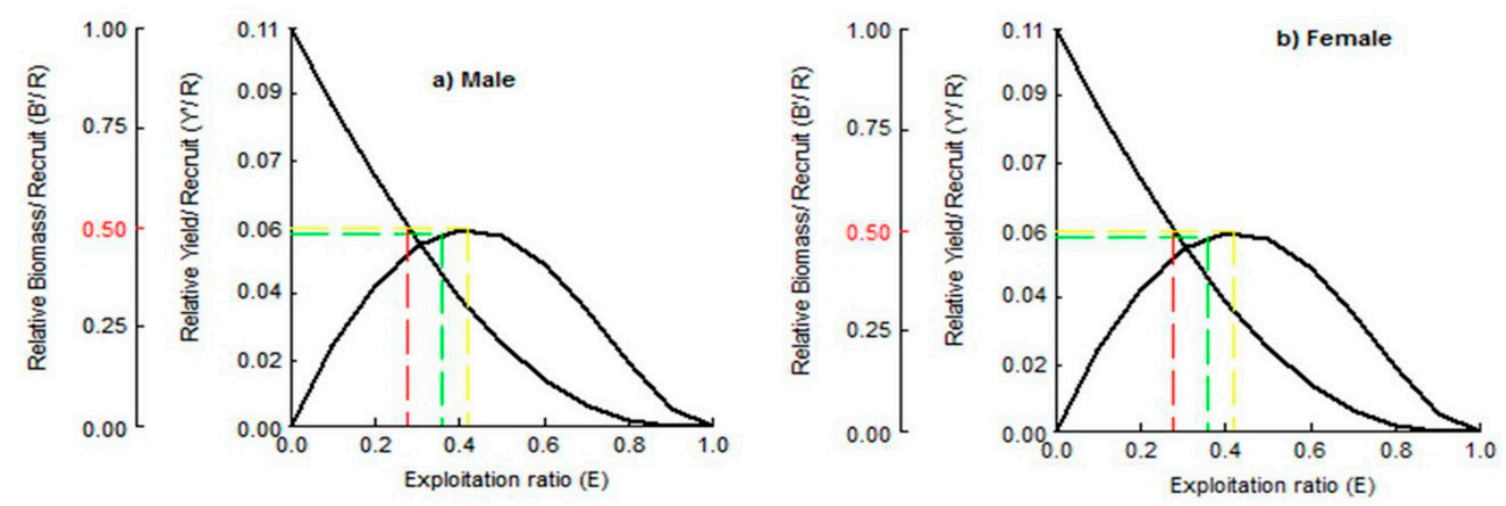

Figure 6. Relationship between the relative yield per recruit $(Y / R)$ and biomass per recruit $(B / R)$ applying knife-edge procedure for males $(\mathbf{a})$ and females $(\mathbf{b})$ of $S$. crassicornis from the Gulf of Suez, Egypt. "Red line $=\mathrm{E}_{0.5}-\mathrm{Green}_{=} \mathrm{E}_{0.1}-$ Yellow $=\mathrm{E}_{\max }{ }^{\prime}$.

\subsection{Molecular Analysis}

Positive PCR amplifications were manifested by the tested samples using the primer pairs of both eukaryotic18S rRNA and COI mitochondrial genes. PCR amplicons of 469 and $683 \mathrm{bp}$ were obtained for the $18 \mathrm{~S}$ rRNA and COI target regions, respectively. BLAST comparisons of the resultant $18 \mathrm{~S}$ rRNA sequences showed $99 \%$ similarity with S. crassicornis, which was confirmed by both the alignment of the obtained COI sequences (99\% similarity with $S$. crassicornis) and the morphological examination results.

The COI sequences obtained for the specimens in our study were assigned a BIN (BOLD ABE7069). BOLD identified the nearest neighbor of the study species as S. koelbeli (BOLD ACS4793), with a p-distance of $0.32 \%$. The analysis of Group Mean genetic distances among S. crassicornis from different countries (Egypt, China, and India) showed that the pairwise distances for the Egyptian S. crassicornis ranged from 0.024 in relation to its Indian 
reference group to 0.048 in relation to the Chinese S. crassicornis counterparts. On the other hand, the estimation of the genetic distance among the species of Solenocera revealed that $S$. melantho was the closest to $S$. crassicornis with a genetic distance of 0.071 . Where, S. pectinata was the most distant from $S$. crassicornis with a genetic distance of 0.27 . Values of genetic distances among species of Solenocera genus are presented in Table 1.

COI-based ML tree (Figure 7) for Solenocera species (from different countries) grouped the studied Solenocera species into two distinct clusters. The first cluster branched into three clades that included S. crassicornis from different countries and S. melantho in the first clade; S. choprai, S. hextii, S. koelbeli, and S. annectens in the second clade. The second cluster included S. pectinate, S. rathbuni, and S. agassizi in the first clade and S. membranacea in the second clade. COI-based ML phylogenetic tree among different species of Solenocera is shown at Figure 7.

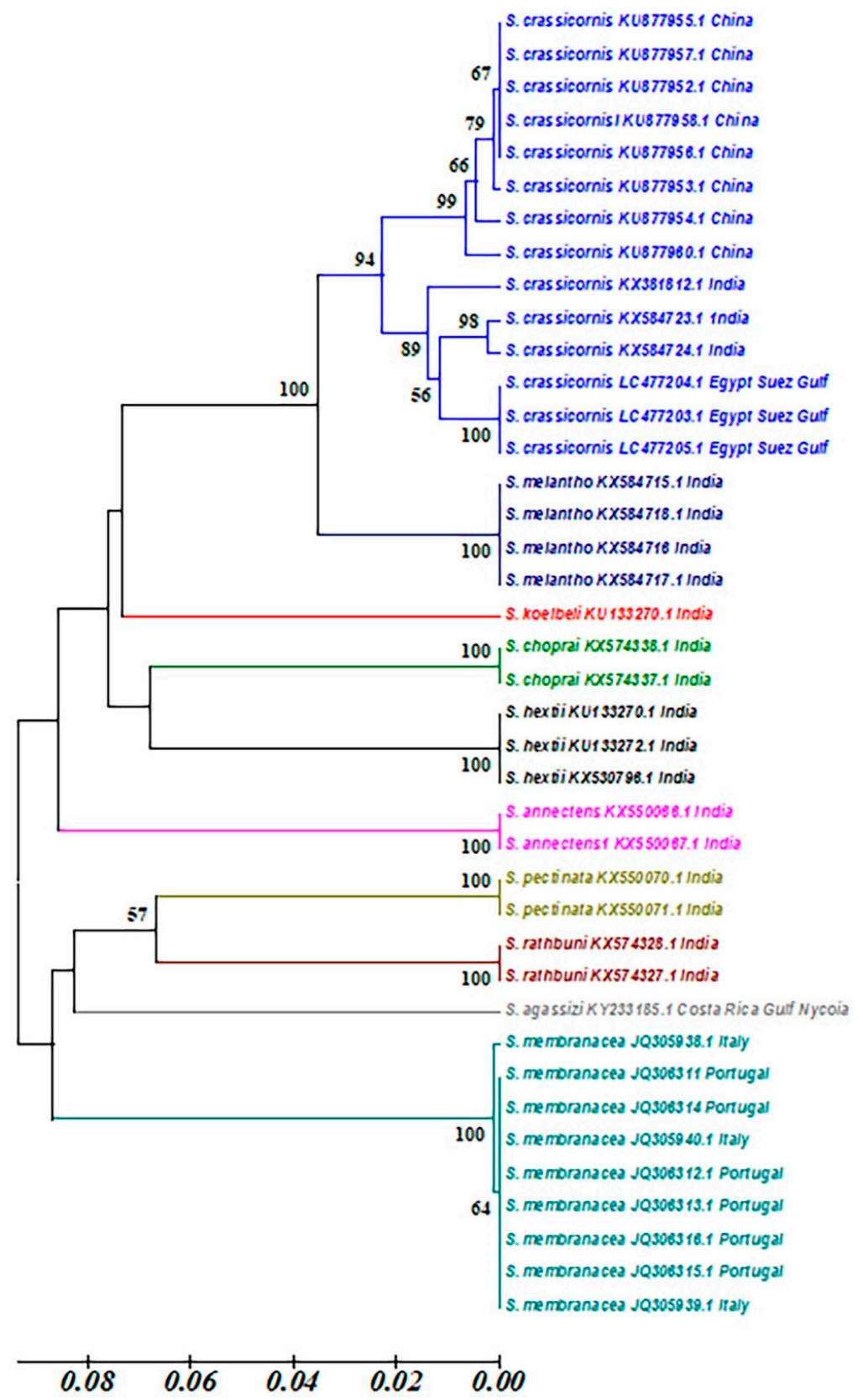

Figure 7. COI-based maximum likelihood (ML) phylogenetic tree among Solenocera species all over the world. 
Table 1. COI (cytochrome oxidase subunit I)-based pairwise genetic distances among Solenocera species worldwide.

\begin{tabular}{|c|c|c|c|c|c|c|c|c|c|c|}
\hline & S. choprai & S. agassizi & S. annectens & S. crassicornis & S. hextii & S. koelbeli & S. melantho & S. membranacea & S. pectinata & S. rathbunt \\
\hline \multicolumn{11}{|l|}{ S. choprai } \\
\hline S. agassizi & 0.203 & & & & & & & & & \\
\hline S. annectens & 0.152 & 0.194 & & & & & & & & \\
\hline S. crassicornis & 0.161 & 0.195 & 0.169 & & & & & & & \\
\hline S. hextii & 0.136 & 0.181 & 0.162 & 0.137 & & & & & & \\
\hline S. koelbeli & 0.228 & 0.226 & 0.229 & 0.146 & 0.190 & & & & & \\
\hline S. melantho & 0.175 & 0.190 & 0.181 & 0.071 & 0.148 & 0.148 & & & & \\
\hline S. membranacea & 0.204 & 0.172 & 0.174 & 0.192 & 0.190 & 0.233 & 0.195 & & & \\
\hline S. pectinata & 0.169 & 0.170 & 0.181 & 0.188 & 0.179 & 0.270 & 0.192 & 0.176 & & \\
\hline S. rathbuni & 0.154 & 0.161 & 0.161 & 0.148 & 0.138 & 0.215 & 0.165 & 0.171 & 0.134 & \\
\hline
\end{tabular}




\section{Discussion}

This novel study introduces S. crassicornis, the lone species of Solenocera in Egypt. Our results provide useful clues about its morphological and molecular characterization, growth parameters, and population dynamics. DNA barcoding has been established as universal tools to identify different species of organisms during the last decade. This molecularbased approach involves sequencing a short and standardized gene region to identify and recognize species such as fish [20]. DNA barcoding does not look to disregard the morphological assessment, and its general purpose is to build an alliance between molecular and morphological taxonomists for quick and unequivocal species identification [30].

Although Solenocera encompasses 38 species, DNA barcoding studies of these species are rare. This study is the first to integrate two molecular markers, namely, the nuclear marker $18 \mathrm{~S}$ rRNA and the mitochondrial marker COI, to characterize S. crassicornis. The analysis of both markers showed $99 \%$ similarity with their reference sequences in the GenBank database, demonstrating a high discrimination level of both markers at a high taxonomic level, and molecular identification matched the morphological identification of the species under examination. The phylogenetic relationship between the Egyptian S. crassicornis and the other S. crassicornis from China and India revealed the close relationship between the specimens from Egypt and their counterparts from India (both of them were clustered in a sub-clade), while the specimens from China were grouped in a separate cluster of the ML tree. These phylogenetic relationships clarified the Indo-West Pacific origin of S. crassicornis $[5,45]$ and suggested its existence in the Red Sea as a migratory species that translocated from the Indian Ocean. This may explain the high comparability despite the natural geographical barrier between these distant areas. Abbas et al. [28] reported that Penaeid shrimps are an effective migratory species that can migrate over vast distances. For instance, Melicertus plebejus was collected approximately $900 \mathrm{~km}$ from its origin in Australia [46]. Interestingly, our study is the first to construct a phylogenetic tree of species of Solenocera capable of separating them according to genetic distance and locating S. crassicornis in the correct position in relation to its close relatives of the same genus.

In the current work, monthly variations of length frequency were utilized to decide the growth parameters of $S$. crassicornis, and to evaluate other population dynamic parameters. The results of morphometric measurements in the present study clearly demonstrated that the female reached both larger size and higher growth rate than males showing sexspecific growth this is due to the higher growth performance index for females than males of the same age group. This observed growth difference is common for many shrimp species $[29,47]$. The population parameters are consistent with that of S. crassicornis estimated growth parameters reported from the same species in other regions $[11,48,49]$. Chakraborty et al. [48] studied the S. crassicornis in in Maharashtra coast and reported that the population dynamics parameters for males and females individually was $L \infty=92 \mathrm{~mm}$, $\mathrm{K}=1.5 \mathrm{yr}^{-1}, \mathrm{Z}=6.00 \mathrm{yr}^{-1}, \mathrm{M}=3.20 \mathrm{yr}^{-1}, \mathrm{~F}=3.60 \mathrm{yr}^{-1}$, and $\mathrm{E}=0.53$ for males and $\mathrm{L}_{\infty}=139 \mathrm{~mm}, \mathrm{~K}=2.00 \mathrm{yr}^{-1}, \mathrm{Z}=10.36 \mathrm{yr}^{-1}, \mathrm{M}=6.92 \mathrm{yr}^{-1}, \mathrm{~F}=3.44 \mathrm{yr}^{-1}$, and $\mathrm{E}=0.67$ for females. Such wide deviations in the growth parameters assessed by different researchers are due to differences in observed sizes, age, sample size, and environmental conditions [50-52]. Pauly et al. [36] cited that the equation could be utilized for shrimps or prawns and any marine invertebrates because these marine organisms share similar resources, habitats, and predators as fish, and they are probably not going to differ widely in their vital parameters [53]. Our results clearly indicated the overfishing situation in the Suez gulf (E $>0.5)$. These results agreed with Xue et al. [11] that studied S. crassicornis in the East China Sea and with Chakraborty et al. [48,49] in Maharashtra coast.

\section{Conclusions}

The current work is a novel study presents S. crassicornis (H. Milne Edwards, 1837), as a lone commercially important shrimp species of the Solenoceridae family (Penaeoidea superfamily) in the Red Sea, Egypt. This species is distributed in the Indo-West Pacific, Japan, China, Hong Kong, and North Borneo. The first record of this species in the 
Mediterranean shelf of Egypt was in 1981, identified as S. indicus (Nataraj, 1945). Our study is the first report investigating this species in Al-Attaka, a commercial landing site of the Gulf of Suez, the Red Sea Shelf of Egypt. Morphological features, molecular identification, and DNA barcoding (18S rRNA nuclear markers and COI mitochondrial markers) were investigated of this species in the Gulf of Suez to precisely identify this Indian-water species as S. crassicornis (H. Milne Edwards, 1837). Despite the social and economic relevance of S. crassicornis in the area, information about the hatching, larval rearing, and farming of S. crassicornis is scarce. Finally, the current novel study is an opportunity to understanding the impacts on wild fisheries of this economic species in the Red Sea, as well as, it is a good opportunity to understanding genetic structures to start breeding programs domestication and selection for aquaculture of this economically commercial species under Egyptian conditions.

Author Contributions: Conceptualization, E.M.A. and Z.Z.S.; methodology, E.M.A., M.A., F.S.A., M.G.D., A.E.-S. and Z.Z.S.; software, E.M.A., Z.Z.S., F.S.A. and M.G.D.; validation, M.G.D., A.E.-S., Z.Z.S., M.M.M. and M.A.; formal analysis, Z.Z.S., M.G.D., F.S.A., M.M.M. and A.E.-S.; investigation, M.A., A.E.-S. and Z.Z.S.; resources, E.M.A. and A.E.-S.; data curation, M.A., Z.Z.S., A.E.-S., M.M.M. and M.G.D.; writing—original draft preparation, E.M.A., F.S.A., M.A., M.G.D. and Z.Z.S.; writingreview and editing, M.A. and A.E.-S.; visualization, E.M.A., A.E.-S. and Z.Z.S.; supervision, E.M.A., M.A. and Z.Z.S.; project administration, E.M.A., A.E.-S. and Z.Z.S.; and funding acquisition, A.E.-S. All authors have read and agreed to the published version of the manuscript.

Funding: This research was funded by the Vice Deanship of Scientific Research Chairs (DSRVCH) at King Saud University.

Institutional Review Board Statement: Not applicable.

Informed Consent Statement: Informed consent was obtained from all subjects involved in the study.

Data Availability Statement: The data presented in this study are available on request from the corresponding authors.

Acknowledgments: The authors are grateful to the Deanship of Scientific Research, King Saud University for funding this research project through Vice Deanship of Scientific Research Chairs (DSRVCH) at King Saud University.

Conflicts of Interest: The authors declare no conflict of interest.

\section{References}

1. Gillett, R. Global Study of Shrimp Fisheries; FAO: Rome, Italy, 2008; Volume 475.

2. Moffitt, C.M.; Cajas-Cano, L. Blue Growth: The 2014 FAO State of the World Fisheries and Aquaculture. Fisheries 2014, $39,552-553$. [CrossRef]

3. Ganesh, P.R.C.; Chakravarty, M.S. Age and growth of the deep water mud shrimp Solenocera melantho (De Man, 1907) of Visakhapatnam coast, India. Indian J. Fish. 2016, 63, 22-27. [CrossRef]

4. Karuppasamy, P.K.; Logeshwaran, V.; Priyadarshini, R.S.S.; Ramamoorthy, N. Molecular and systematic identification of food marine shrimps using mtCOI marker from Southeast Coast of India. Thalass: Int. J. Mar. Sci. 2020, 1-9. [CrossRef]

5. Holthuis, L.B. Shrimps and Prawns of the World. An Annotated Catalogue of the Species of Interest to Fisheries; FAO: Rome, Italy, 1980.

6. Muthu, M.S.; George, M.J. Solenocera indica Nataraj, one of the commercially important prawns of Indian waters as a synonym of Solenocera crassicornis (H. Milne Edwards). J. Mar. Biol. Assoc. India 1972, 13, 142-143.

7. Jin, L.; Ding, G.; Li, P.; Gu, J.; Zhang, X. Changes in quality attributes of marine-trawling shrimp (Solenocera crassicornis) during storage under different deep-frozen temperatures. J. Food Sci. Technol. 2018, 55, 2890-2898. [CrossRef]

8. Kunju, M.M. Observations on the prawn fishery of Maharaslitra Coast. Proc. Symp. Crustacea Mar. Biol. Assoc. India 1967, 4, 1382-1397.

9. Mohamed, K.H. Penaeid prawn in the commercial shrimp fisheries of Bombay with note on species and size fluctuations. Proc. Symp. Crustacea Mar. Biol. India. 1967, 4, 1408-1418.

10. Sukumaran, K.K. Studies on the fishery and biology of Solenocera crassicornis (H. Milne Edwards) from Bombay waters. J. Mar. Biol. Assoc. India 1978, 20,32-40.

11. Xue, L.J.; He, Z.T.; Xu, K.D.; Song, H.T. Population dynamics and estimation of sustainable yield for Solenocera crassicornis in the East China Sea. J. Fujian Fish. 2009, 4, 48-54. 
12. Rajkumar, G.; Bhavan, S.B.; Udayasuriyan, R.; Vadivalagan, C. Molecular identification of shrimp species, Penaeus semisulcatus, Metapenaeus dobsoni, Metapenaeus brevicornis, Fenneropenaeus indicus, Parapenaeopsis stylifera and Solenocera crassicornis inhabiting in the coromandel coast (Tamil Nadu, India) using MT-COI gene. Int. J. Fish. Aquat. Stud. 2015, 2, 96-106.

13. GAFRD. The General Authority for the Development of fish Resources, Annual Report 2018; GAFRD: Kafr EL-Sheikh, Egypt, 2018.

14. Abo-Taleb, H.; Ashour, M.; El-Shafei, A.; Alataway, A.; Maaty, M.M. Biodiversity of Calanoida Copepoda in Different Habitats of the North-Western Red Sea (Hurghada Shelf). Water 2020, 12, 656. [CrossRef]

15. Abdel-Razek, F.A.; El-Hawary, M.M.; Halim, Y.; Drohisheva, S.S. A new Indo-Pacific penaeid in the Mediterranean, Solenocera indica Nataraj. Bull. Inst. Oceanogr. Fish. 1981, 7, 575-577.

16. Ashour, M.; Abo-Taleb, H.A.; Abou-Mahmoud, M.M.; El-Feky, M.M.M. Effect of the integration between plankton natural productivity and environmental assessment of irrigation water, El-Mahmoudia Canal, on aquaculture potential of Oreochromis niloticus. Turk. J. Fish. Aquat. Sci. 2018, 18, 1163-1175. [CrossRef]

17. Ashour, M.; Elshobary, M.E.; El-Shenody, R.; Kamil, A.-W.; Abomohra, A.E.-F. Evaluation of a native oleaginous marine microalga Nannochloropsis oceanica for dual use in biodiesel production and aquaculture feed. Biomass Bioenergy 2019, 120, 439-447. [CrossRef]

18. El-Shenody, R.A.; Ashour, M.; Ghobara, M.M.E. Evaluating the chemical composition and antioxidant activity of three Egyptian seaweeds Dictyota dichtoma, Turbinaria decurrens, and Laurencia obtuse. Braz. J Food Tech. 2019, 22, e2018203. [CrossRef]

19. Montgomery, S. Biology and life cycles of prawns. Primefact No. 268. Ind. Invest. NSW Aust. 2010, 8, $1832-6668$.

20. Hebert, P.D.N.; Cywinska, A.; Bali, S.L.; Dewaard, J.R. Biological identifications through DNA barcodes. Proc. R. Soc. Lond. Ser. B-Biol. Sci. 2003, 270, 313-321. [CrossRef]

21. Elshobary, M.; El-Shenody, R.; Ashour, M.; Zabed, H.M.; Qi, X. Antimicrobial and antioxidant characterization of bioactive components from Chlorococcum minutum, a newly isolated green microalga. Food Biosci. 2020, 35, 100567. [CrossRef]

22. Hajibabaei, M.; Ivanova, N.V.; Ratnasingham, S.; Dooh, R.T.; Kirk, S.L.; Mackie, P.M.; Hebert, P.D. Critical factors for assembling a high volume of DNA barcodes. Philos. Trans. R. Soc. Lond. B-Biol. Sci. 2005, 360, 1959-1967. [CrossRef]

23. Ali, F.S.; Ismail, M.; Mamoon, A. Comparative molecular identification of genus Dicentrarchus using mitochondrial genes and internal transcribed spacer region. Egy. J. Aqua. Biol. Fish. 2019, 23, 371-384. [CrossRef]

24. Folmer, O.; Black, M.; Hoeh, W.; Lutz, R.; Vrijenhoek, R. DNA primers for amplification of mitochondrial cytochrome c oxidase subunit I from diverse metazoan invertebrates. Mol. Mar. Biol. Biotechnol. 1994, 3, 294-299. [PubMed]

25. Voloch, C.; Freire, P.; Russo, C.A.M. Molecular phylogeny of peneid shrimps inferred from two mitochondrial markers. Genet. Mol. Res. GMR 2005, 4, 668-674. [PubMed]

26. Wilson, J.J.; Sing, K.W. DNA Barcoding Can Successfully Identify Penaeus monodon, Associate Life Cycle Stages, and Generate Hypotheses of Unrecognised Diversity. Sains Malays. 2013, 42, 1827-1829.

27. Abbas, E.; Abdelsalam, K.; Geba, K.M.; Ahmed, H.; Kato, M. Genetic and morphological identification of some crabs from the Gulf of Suez, Egypt. J. Aqua. Res. 2016, 42, 319-329. [CrossRef]

28. Abbas, E.M.; Geba, K.M.; Sharawy, Z.Z. Molecular and biometric characterizations of the Western king prawn Melicertus latisulcatus (Kishinouye, 1896) in the Egyptian Red Sea. Egy. J. Aqua. Biol. Fish. 2018, 22, 1-14. [CrossRef]

29. Sharawy, Z.; Abbas, E.M.; Desouky, M.G.; Kato, M. Descriptive analysis and molecular identification of the green tiger shrimp Penaeus semisulcatus (De Haan, 1844) in Suez Gulf, Red Sea. Inter. J. Fish. Aquat. Stud. 2016, 4, 426-432.

30. Sharawy, Z.Z.; Abbas, E.M.; Khafage, A.R.; Galal-Khallaf, A.; Ismail, R.F.; Omar, A.A.; Geba, K.M.; Kato, M. Descriptive analysis, DNA barcoding and condition index of Penaeids (Crustacea: Decapoda) from the Egyptian Mediterranean coast. Fish. Res. 2017, 188, 6-16. [CrossRef]

31. Sharawy, Z.Z.; Ashour, M.; Abbas, E.; Ashry, O.; Helal, M.; Nazmi, H.; Kelany, M.; Kamel, A.; Hassaan, M.; Rossi, W.J.; et al. Effects of dietary marine microalgae, Tetraselmis suecica on production, gene expression, protein markers and bacterial count of Pacific white shrimp Litopenaeus vannamei. Aqua. Res. 2020, 51, 2216-2228. [CrossRef]

32. Bertalanffy, V.L. A quantitative theory of organic growth (Inquiries on growth laws II). Hum. Biol. 1938, 10, 181-213.

33. Pauly, D.; Munro, J.L. Once more on the comparison of growth in fish and invertebrates. Fishbyte 1984, 2, 1-21.

34. Pauly, D. On the interrelationships between natural mortality, growth parameters and mean environmental temperature in 175 fish stocks. ICES J. Mar. Sci. 1980, 39, 17-92. [CrossRef]

35. Gulland, J.A. The fish resources of the Ocean. West Byfleet, Surrey; Fishing News (Books), Ltd., FAO: Rome, Italy, 1971.

36. Pauly, D.A. Review of the ELEFAN system for analysis of length frequency data in fish and invertebrates. In Length-based Methods in Fisheries Research. ICLARM Conference Proceedings 13; Pauly, D., Morgan, G.R., Eds.; ICLARM: Manila, Philippines, 1987.

37. Beverton, R.J.H.; Holt, S.J. Manual of methods for fish stock assessment. Tables of yield functions. FAO Fish. Tech. Pap./FAO 1966, 38, 1-67.

38. Pauly, D.; Soriano, M.L. Some practical extensions to Beverton and Holt's relative yield-per-recruit model. In The First Asian Fisheries Forum; Maclean, J.L., Dizon, L.B., Hosillo, L.V., Eds.; Asian Fisheries Society: Manila, Philippines, 1986; pp. $491-496$.

39. Le-Cren, E.D. The length-weight relationship and seasonal cycle in gonad weight and condition on the perch (Perca fluviatilis). J. Anim. Ecol. 1951, 20, 201-219. [CrossRef]

40. Sambrook, J.; Edward, F.F.; Tom, M. Molecular Cloning: A Laboratory Manual, 2nd ed.; Cold Spring Harbor Laboratory Press: Cold Spring Harbor, NY, USA, 1989.

41. Abbas, E.M.; Takayanagi, A.; Shimizu, N.; Kato, M. Methylation status and chromatin structure of the myostatin gene promoter region in the sea perch Lateolabrax japonicus (Perciformes). Gene. Mol. Res. 2011, 10, 3306-3315. [CrossRef] 
42. Ratnasingham, S.; Hebert, P.D. A DNA-based registry for all animal species: The Barcode Index Number (BIN) system. PLoS ONE 2013, 8, e66213. [CrossRef] [PubMed]

43. Kimura, M. A simple method for estimating evolutionary rates of base substitutions through comparative studies of nucleotide sequences. J. Mol. Evol. 1980, 16, 111-120. [CrossRef]

44. Kumar, S.; Stecher, G.; Tamura, K. MEGA7: Molecular Evolutionary Genetics Analysis version 7.0 for bigger datasets. Mol. Biol. Evol. 2016, 33, 1870-1874. [CrossRef]

45. Dall, W.H.B.J.; Hill, B.J.; Rothlisberg, P.C.; Sharples, D.J. The biology of the Penaeidae. Adv. Mar. Biol. 1990, $27,1-489$.

46. Ruello, N.V. Geographical distribution, growth and breeding miagration of the eastern Australian king prawn Penaeus plebejus Hess. Mar. Freshw. Res. 1975, 26, 343-354. [CrossRef]

47. Baelde, P. Growth, mortality and yield-per-recruit of deep-water royal red prawns (Haliporoides sibogae) of eastern Australia, using the length-based MULTIFAN method. Mar. Biol. 1994, 118, 617-625. [CrossRef]

48. Chakraborty, S.K.; Desmukh, V.D.; Zaffarkhan, M.; Vidyasagar, K.; Raje, S.G. Estimates of growth, mortality, recruitment pattern and MSY of important resources from the Maharashtra coast. J. Indian Fish. Assoc. 1994, 24, 1-39.

49. Chakraborty, S.K.; Deshmukh, V.D.; Kahn, M.Z.; Vidyasagar, K.; Raje, S.G. Estimate of growth, mortality, recruitment pattern and maximum sustainable yield of important fishery resources of Maharashtra coast. Indian J. Mar. Sci. 1997, $26,53-56$.

50. Heneash, A.; Ashour, M.; Matar, M. Effect of Un-live Microalgal diet, Nannochloropsis oculata and Arthrospira (Spirulina) platensis, comparing to yeast on population of rotifer, Brachionus plicatilis. Mediterr. Aquac. J. 2015, 7, 48-54. [CrossRef]

51. Abo-Taleb, H.A.; Zeina, A.F.; Ashour, M.; Mabrouk, M.M.; Sallam, A.E.; El-feky, M.M.M. Isolation and cultivation of the freshwater amphipod Gammarus pulex (Linnaeus, 1758), with an evaluation of its chemical and nutritional content. EJABF 2020, 24, 69-82. [CrossRef]

52. Ashour, M.; El-Shafei, A.; Khairy, H.M.; Abd-Elkader, D.Y.; Mattar, M.A.; Alataway, A.; Hassan, S.M. Effect of Pterocladia capillacea Seaweed Extracts on Growth Parameters and Biochemical Constituents of Jew's Mallow. Agronomy 2020, 10, 420. [CrossRef]

53. Sharawy, Z.Z.; Hufnag, M.; Temming, A. A condition index based on dry weight as a tool to estimate in-situ moult increments of decapod shrimp: Investigating the effects of sex, year and measuring methods in brown shrimp (Crangon crangon). J. Sea Res. 2019, 152, 101762. [CrossRef] 